\title{
ANALISIS RESPON MAHASISWA TERHADAP PEMBELAJARAN DARING MENGGUNAKAN MEDIA PEMBELAJARAN GOOGLE CLASSROOM
}

\author{
Syamsuriana Basri, Reski Idamayanti, Yusdarina \\ Program Studi Pendidikan Fisika, FKIP, Universitas Muslim Maros \\ Email: syamsuriana@umma.ac.id
}

Diterima: 15 Juli 2021. Direvisi: 22 Agustus 2021. Disetujui: 30 September 2021.

\begin{abstract}
Abstrak
Penelitian ini adalah penelitian deskriptif yang bertujuan untuk mengetahui gambaran respon mahasiswa terhadap pembelajaran daring menggunakan google classroom. Subjek penelitian ini adalah Mahasiswa Prodi Pendidikan Fisika semester VI angkatan 2018 Program Studi Pendidikan Fisika pada mata kuliah Pengembangan Bahan Ajar Fisika Berbasis Kearifan Lokal sebanyak 12 orang. Penelitian ini dilaksanakan dalam 12 kali pertemuan dan pengambilan data dilakukan dengan menggunakan kuesioner melalui google form. Kuesioner Respon Mahasiswa dianalisis secara kuantitatif menggunakan analisis deskriptif dan diagram diambil langsung pada google form. Hasil penelitian menunjukkan bahwa mahasiswa merespon positif pembelajaran daring menggunakan media google classroom yang digunakan pada mata kuliah pengembangan bahan ajar fisika berbasis kearifan lokal dengan persentase $74 \%$ pada aspek efektif dan efisensi pembelajaran daring dan $24 \%$ pada aspek aspek tanggung jawab dalam pembelajaran daring.

Kata kunci: Pembelajaran daring, google classroom, dan pengembangan bahan ajar fisika berbasis kearifan lokal
\end{abstract}

\begin{abstract}
This study is a descriptive study that aims to describe the student's response to online learning using google classroom. The subjects of this study were students of the sixth semester of Physics Education Study Program class of 2018 Physics Education Study Program in the subject of Development of Physics Teaching Materials Based on Local Wisdom as many as 12 people. This research was conducted in 12 meetings and data collection was carried out using a questionnaire via google form. The Student Response Questionnaire was analyzed quantitatively using descriptive analysis and the diagrams were taken directly on the google form. The results showed that students responded positively to online learning using google classroom media which was used in the development of physics teaching materials based on local wisdom with a percentage of $74 \%$ on the effective and efficient aspects of online learning and $24 \%$ on the aspects of responsibility in online learning.
\end{abstract}

Keywords: Online learning, google classroom, and the development of physics teaching materials based on local wisdom 
Basri., Idamayanti., Yusdarina. - Analisis Respon Mahasiswa ...

PENDAHULUAN

Sejak bulan Maret 2020, Indonesia termasuk dalam salah satu Negara yang terkena dampak pandemi virus corona SARS-CoV2 (Covid-19). Pemerintah Indonesia mulai tanggap untuk menganjurkan warganya menerapkan social distancing atau mengisolasi diri dirumah untuk mengantisipasi penyebaran virus yang semakin cepat penyebarannya.

Semakin meluasnya penyebaran virus Covid-19 berdampak pada berbagai sektor, tidak terkecuali pada sektor pendidikan. Berdasarkan Surat Edaran Nomor 4 Tahun 2020 tentang Pelaksanaan Kebijakan Pendidikan dalam Masa Darurat Penyebaran Corona Virus Disease (COVID-19) oleh Menteri Pendidikan dan Kebudayaan Republik Indonesia terkait pembelajaran dilakukan dari rumah. Sehingga berdasarkan kebijakan pemerintah di masa darurat untuk mengatisipasi penyebaran COVID-19 dan guna memutus mata rantai penyebaran seluruh sekolah maupun perguruan tinggi di Indonesia dianjurkan menggunakan sistem belajar dari rumah atau sistem pembelajaran Daring (dalam jaringan).

Sistem pembelajaran daring merupakan sistem pembelajaran tanpa tatap muka secara langsung antara guru dan siswa tetapi dilakukan melalui online yang menggunakan jaringan internet. Guru harus memastikan kegiatan belajar mengajar tetap berjalan, meskipun siswa berada di rumah. Solusinya, guru dituntut dapat mendesain media pembelajaran sebagai inovasi dengan memanfaatkan media daring (Nirfayanti \& Nurbaeti, 2019).

Demikian pula dengan dosen, dosen melaksanakan pembelajaran daring yang diharapakan dengan pembelajaran daring tersebut tidak mengurangi eksistensi seorang dosen ketika mengajar dengan tatap muka sehingga dosen berupaya penuh untuk melakukan pembelajaran yang inovatif agar materi perkuliahan dapat tersampaikan secara efektif dan efisien. Beberapa mata kuliah praktikum telah dilaksanakan secara blended learning dengan pembelajaran luring untuk mata kuliah yang membutuhkan praktikum dengan mematuhi protokol kesehatan 
Basri., Idamayanti., Yusdarina. - Analisis Respon Mahasiswa ...

serta membatasi jumlah mahasiswa yang masuk laborotorium yaitu hanya berjumlah 5 orang (Basri et al., 2021). Hal ini berarti beberapa metode pebelajaran dilakukan oleh dosen agar pembelajaran tetap dapat tersampaikan sesuai dengan tujuan pembelajaran yang ingin dicapai, meskipun tidak diwajibkan sepenuhnya sebab resiko akan lebih besar.

Sehubungan dengan pelaksanaan pembelajaran daring ini berbagai media yang digunakan oleh dosen menggunakan perangkat personal computer (PC) atau laptop yang tentunya terkoneksi dengan jairngan internet. Media yang digunakan di Universitas Muslim Maros, pada umumnya adalah media pembelajaran google classroom yang telah disediakan oleh pihak kampus. Google classroom sesungguhnya dirancang untuk mempermudah interaksi dosen dan mahasiswa dalam dunia maya. Aplikasi ini memberikan kesempatan kepada para dosen untuk mengeksplorasi gagasan keilmuan yang dimilikinya kepada mahasiswa. Sejalan dengan Hapsari dan Pamungkas (2019) yang menyatakan Google Classroom, adalah salah satu akses gratis yang memudahkan dosen dalam proses elearning. Sementara itu Utami (2019) menyatakan respon yang baik ditunjukan oleh mahasiswa dalam penggunaan Google Classroom sehingga Google Classroom dapat digunakan untuk memperlancar proses pembelajaran.

Lebih jauh, platform ini menawarkan banyak sekali keuntungan bagi penggunanya. Dosen memiliki keleluasaan waktu untuk membagikan kajian keilmuan dan memberikan tugas mandiri kepada mahasiswa (Nirfayanti \& Nurbaeti, 2019).

Faktor pendukung pelaksanaan google classroom antara lain kesiapan SDM untuk meningkatkan pembelajaran elearning, fasilitas software untuk mengembangkan media pembelajaran, fasilitas sarana internet, dan kebutuhan pelaksanaan media pembelajaran untuk meningkatkan dan menambah aktivitas pembelajaran di kelas. Faktor penghambat pelaksanaan pembelajaran google classroom antara lain: kurangnya motivasi dalam 
Basri., Idamayanti., Yusdarina. - Analisis Respon Mahasiswa ...

mengembangkan pembelajaran
google classroom dikarenakan
tersedianya fasilitas belajar yang lain

di kelas (Sabran \& Sabara Eddy, 2017).

Beberapa penelitian telah dilakukan untuk melihat beberapa respon dikalangan mahasiswa diantaranya (Widayati, 2020) menjelaskan pada penelitianya bahwa dengan pembelajaran daring ternyata efektif dalam proses pembelajaran dimasa pandemi ini. Berbeda dengan hasil penelitian yang dilakukan oleh (Akhmad, 2019) mengatakan walaupun pembelajaran online memberikan kemudahan dalam belajar namun ternyata pembelajaran secara online ini bisa dibilang belum efektif dan efesien dalam pemahaman siswa dalam belajar. Selain itu, penggunaan google classrom juga memiliki banyak manfaat, seperti dapat membuat absen, kuis, kuesioner secara online.

Penelitian ini bertujuan untuk melihat respon mahasiswa selama pembelajaran daring menggunakan media pembelajaran google classroom. Respon mahasiswa dapat berupa respon positif dan respon negatif.

\section{METODE}

Jenis penelitian yang digunakan adalah penelitian deksriptif, metode penelitian yang digunakan dalam penelitian ini adalah metode penelitian kuantitatif. Metode penelitian kuantitatif diartikan sebagai metode penelitian yang berlandaskan pada filsafat positivisme digunakan untuk meneliti pada populasi atau sampel tertentu dan analisis data bersifat kuantitatif (Sugiyono, 2018).

Cara pengambilan data menggunakan kuesioner google form, kemudian dianalisis dengan data deskriptif kuantitatif dengan menghitung persentasi setiap pernyataan pada aspek Respon. Data yang dianalisis dengan menggunakan statistik deskriptif yaitu dengan menyajikan data dalam bentuk Histogram, perhitungan mean dan tabel.

Populasi dalam penelitian ini seluruh Mahasiswa Prodi Pendidikan Fisika. Sampel dalam penelitian ini adalah mahasiswa mahasiswa semester VI Prodi Pendidikan Fisika. Teknik penarikan sampel yang 
Basri., Idamayanti., Yusdarina. - Analisis Respon Mahasiswa ...

digunakan dalam penelitian ini adalah sampel jenuh sebab semua anggota populasi digunakan sebagai sampel. Menurut sampling jenuh adalah teknik penentuan sampel bila semua anggota populasi digunakan sebagai sampel (Setyosari, 2016).

Adapun Indikator yang digunakan dalam penelitian ini terdapat pada Tabel 1.

Tabel 1. Rubrik Penilaian Respon Mahasiswa terhadap Pembelajaran Daring dengan Menggunakan Media Pembelajaran Google Classroom

\begin{tabular}{|c|c|}
\hline Aspek & Pernyataan \\
\hline \multirow{11}{*}{$\begin{array}{l}\text { Efektifitas dan } \\
\text { Efesiensi Pembelajaran } \\
\text { Daring }\end{array}$} & Google Classroom meningkatkan performa pembelajaran mahasiswa \\
\hline & $\begin{array}{l}\text { Google Classroom dapat meningkatkan produktivitas dalam } \\
\text { pembelajaran }\end{array}$ \\
\hline & Google Classroom sangat berguna dalam proses pembelajaran \\
\hline & Kemudahan dalam mengakses Google Classroom \\
\hline & $\begin{array}{l}\text { Kemudahan dalam penggunaan Google Classroom sesuai yang } \\
\text { diinginkan }\end{array}$ \\
\hline & Google Classroom menarik perhatian mahasiswa dalam pembelajaran \\
\hline & $\begin{array}{l}\text { Google Classroom memungkinkan mahasiswa mendapatkan umpan balik } \\
\text { secara lebih cepat }\end{array}$ \\
\hline & $\begin{array}{l}\text { Mahasiswa senang menggunakan Google Classroom dalam } \\
\text { pembelajaran }\end{array}$ \\
\hline & Tampilan Google Classroom sangat jelas dan mudah dipahami \\
\hline & $\begin{array}{l}\text { Dengan Google Classroom, memperoleh pengumuman, materi } \\
\text { maupun pengumpulan tugas menjadi lebih fleksibel }\end{array}$ \\
\hline & $\begin{array}{l}\text { Google Classroom memudahkan saya untuk menyimpan dokumen } \\
\text { materi maupun tugas yang penting }\end{array}$ \\
\hline \multirow{4}{*}{$\begin{array}{l}\text { Tanggung Jawab } \\
\text { dalam Pembelajaran } \\
\text { Daring }\end{array}$} & Google $\quad$ classroom $\quad$ dapat menghemat waktu dan biaya \\
\hline & $\begin{array}{l}\text { Menggunakan Google Classroom memungkinkan dalam menyelesaikan } \\
\text { tugas } \\
\text { Mahasiswa lebih semangat mengerjakan tugas melalu proses } \\
\text { pembelajaran daring }\end{array}$ \\
\hline & $\begin{array}{l}\text { Pembelajaran daring membuat lebih bertanggung jawab dalam } \\
\text { mengerjakan tugas }\end{array}$ \\
\hline & Pembelajaran daring megantisipasi pengerjaan tugas secara tepat waktu \\
\hline
\end{tabular}

HASIL DAN PEMBAHASAN

Efektivitas dan Efisensi

\section{Pembelajaran daring}

Hasil Penelitian Respon

Mahasiswa pada Indikator efektif dan efisiensi pembelajaran daring dapat dilihat pada Gambar 1. Berdasarkan
Gambar 1, respon dengan kategori tertinggi berada pada respon positif sehingga umumnya mahasiswa memiliki respon positif mengenai efektif dan efisiensi pembelajaran daring. Hasil respon mahasiswa pada indikator efektif dan efisiensi 
Basri., Idamayanti., Yusdarina. - Analisis Respon Mahasiswa ...

pembelajaran daring pada setiap gambarkan respon penggunaan pernyataan-pertanyaan yang meng- google classroom bagi pembelajaran.

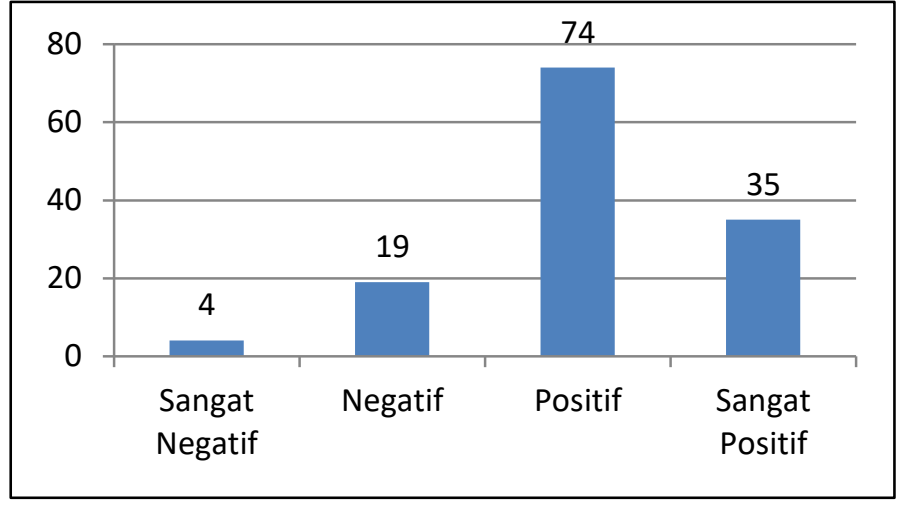

Gambar 1. Grafik Respon Mahasiswa pada Aspek Efektivitas dan Efisensi Pembelajaran Daring.

Pada pernyataan google meningkatkan performa pemclassroom meningkatkan performa belajaran mahasiswa, respon pembelajaran mahasiswa dapat mahasiswa berada pada kategori dilihat pada Gambar 2. Berdasarkan positif.

Gambar 2 dapat disimpulkan pada pernyaataan google classroom

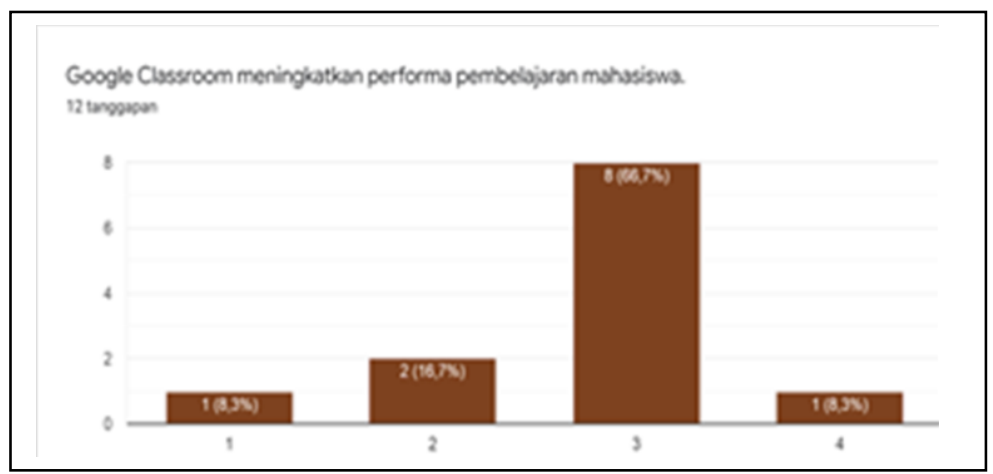

Gambar 2. Respon Pengaruh Penggunaan Google Classroom terhadap Peningkatkan performa pembelajaran mahasiswa

Selanjutnya pada pernyataan Gambar 3. Dari Gambar 3, dapat Google Classroom dapat disimpulkan pada pernyaataan meningkatkan produktivitas dalam Google Classroom dapat pembelajaran dapat dilihat pada meningkatkan produktivitas dalam 
Basri., Idamayanti., Yusdarina. - Analisis Respon Mahasiswa ...

pembelajaran berada pada kategori positif.

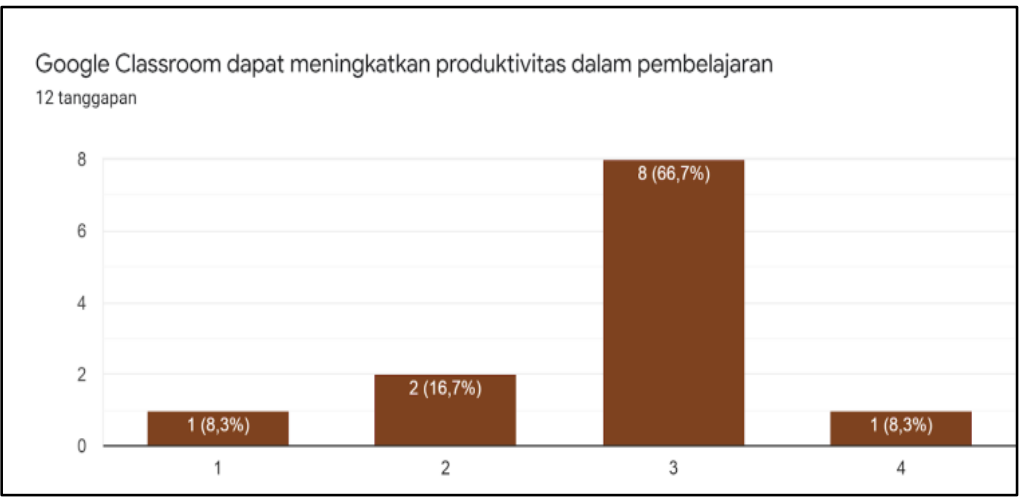

Gambar 3. Respon Pengaruh Penggunaan Google Classroom terhadap Peningkatkan Produktivitas dalam Pembelajaran

Terkait kemudahan dalam dapat disimpulkan pada pernyaataan mengakses Google Classroom, kemudahan dalam mengakses Google respon mahasiswa dapat dilihat pada Classroom berada pada kategori Gambar 4. Berdasarkan respon sangat positif. seperti ditunjukkan pada Gambar 4,

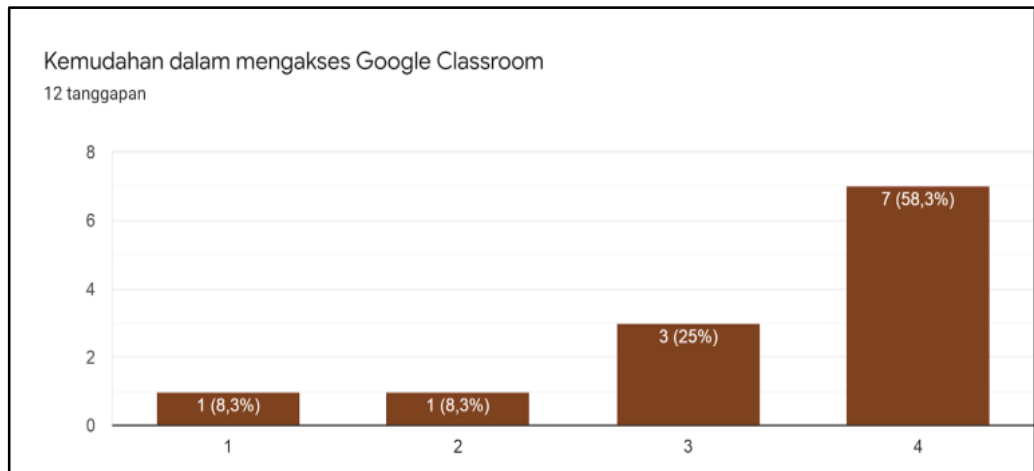

Gambar 4. Respon Kemudahan dalam Mengakses Google Classroom

Sementara itu, pada pernyataan menjawab negatif, $58,3 \%$ menjawab Kemudahan dalam penggunaan positif dan 33,3\% menjawab sangat Google Classroom sesuai yang positif. Berdasarkan data tersebut diinginkan, dilihat pada Gambar 5. dapat disimpulkan bahwa respon

Dari Gambar 5, tdiketahui $0 \%$ penggunaan Google Classroom menjawab sangat negatif, $8,3 \%$ berada pada kategori positif. 
Basri., Idamayanti., Yusdarina. - Analisis Respon Mahasiswa ...

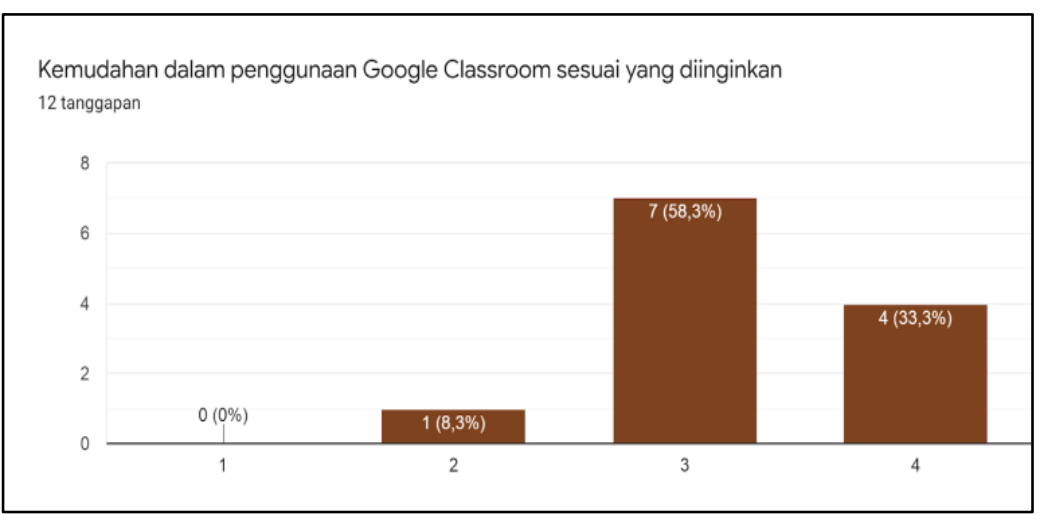

Gambar 5. Respon Kemudahan dalam Penggunaan Google Classroom

Selanjutnya, pada pernyataan hal ini ditunjukkan oleh respon $0 \%$ Google Classroom menarik perhatian menjawab sangat negatif, 25\% mahasiswa dalam pembelajaran, menjawab negatif, 66,7\% menjawab dilihat pada Gambar 6. Dari Gambar positif dan 8,3\% menjawab sangat 6, diketahui Google Classroom positif.

mampu menarik perhatian mahasiswa

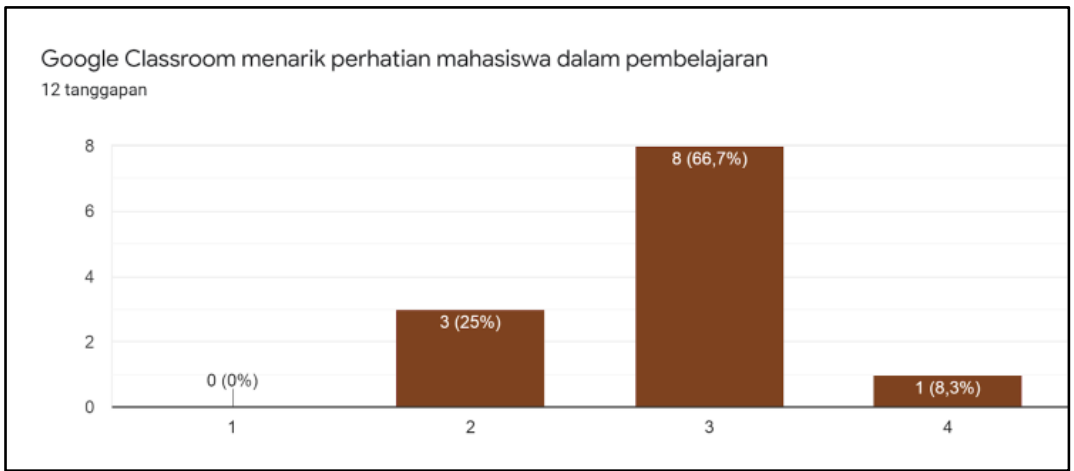

Gambar 6. Histogram pernyataan google classroom menarik perhatian mahasiswa dalam pembelajaran

Selanjutnya, pada pernyataan Google Classroom memungkinkan mahasiswa mendapatkan umpan balik secara lebih cepat, dilihat pada Gambar 7. Berdasarkan Gambar 7,
Google Classroom memungkinkan mahasiswa mendapatkan umpan balik secara lebih cepat. 
Basri., Idamayanti., Yusdarina. - Analisis Respon Mahasiswa ...

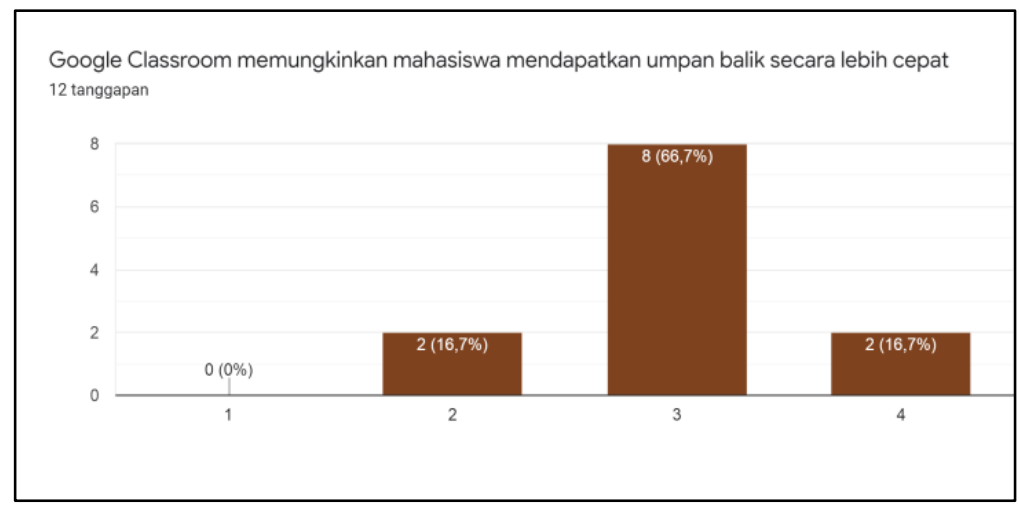

Gambar 7. Histogram pernyataan memungkinkan mahasiswa mendapatkan umpan balik secara lebih cepat

Selanjutnya, berdasarkan positif dan $8,3 \%$ menjawab sangat Gambar 8, terkait pernyataan rasa positif. Sehingga, dapat disimpulkan senang Mahasiswa dalam bahwa mahasiswa senang menggunakan Google Classroom menggunakan Google Classroom dalam pembelajaran menunjukkan 0 dalam pembelajaran.

$\%$ menjawab sangat negatif, $16,7 \%$

menjawab negatif, $75 \%$ menjawab

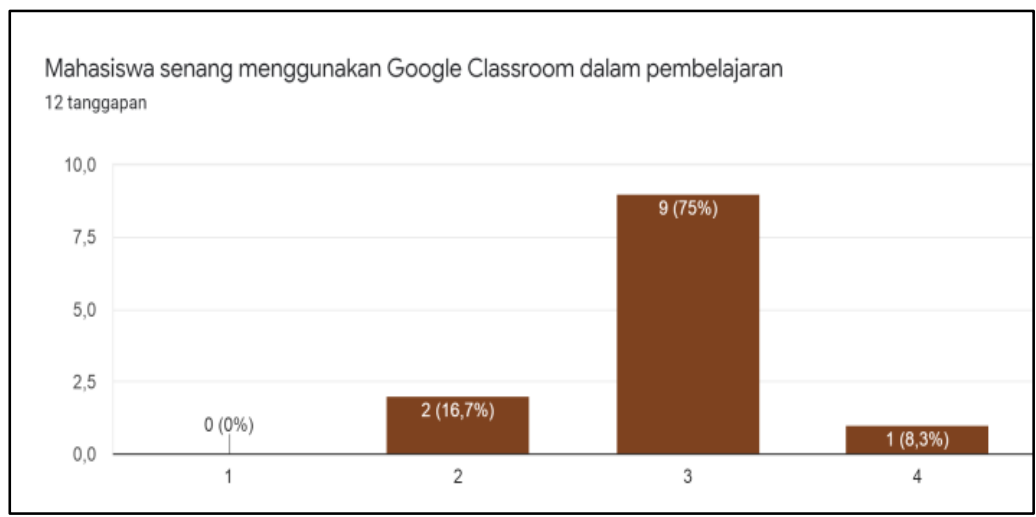

Gambar 8. Histogram pernyataan mahasiswa senang menggunakan google classroom dalam pembelajaran

Berdasarkan Gambar 9, 41,7\% menjawab positif dan 50\% diketahui bahwa Google Classroom menjawab sangat positif. Sehingga sangat jelas dan mudah dipahami dapat disimpulkan bahwa tampilan menunjukkan $0 \%$ menjawab sangat Google Classroom sangat jelas dan negatif, $8,3 \%$ menjawab negatif, mudah dipahami. 
Basri., Idamayanti., Yusdarina. - Analisis Respon Mahasiswa ...

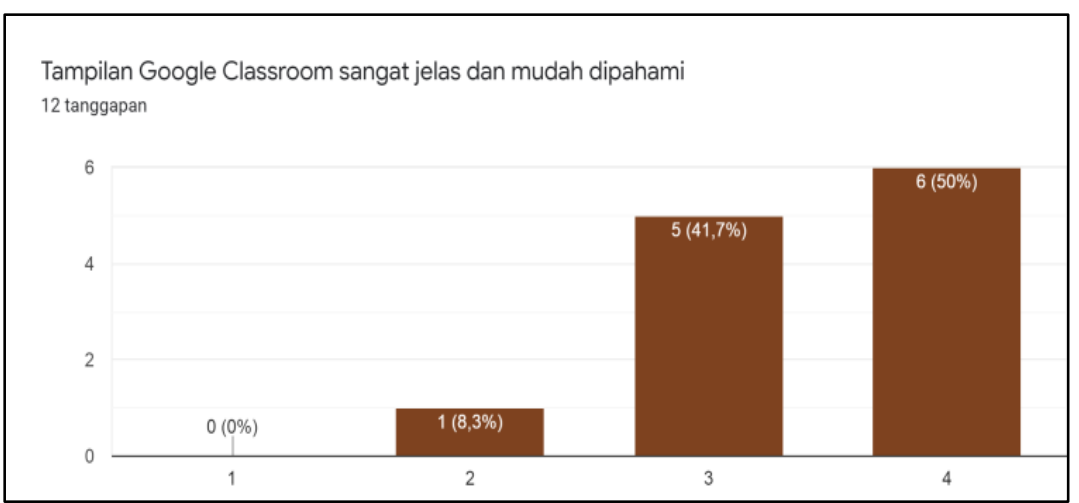

Gambar 9. Histogram pernyataan sangat jelas dan mudah dipahami

Selanjutnya, pada pernyataan lebih fleksibel, dilihat pada grafik dengan Google Classroom, histogram seperti ditunjukkan pada memperoleh pengumuman, materi Gambar 10.

maupun pengumpulan tugas menjadi

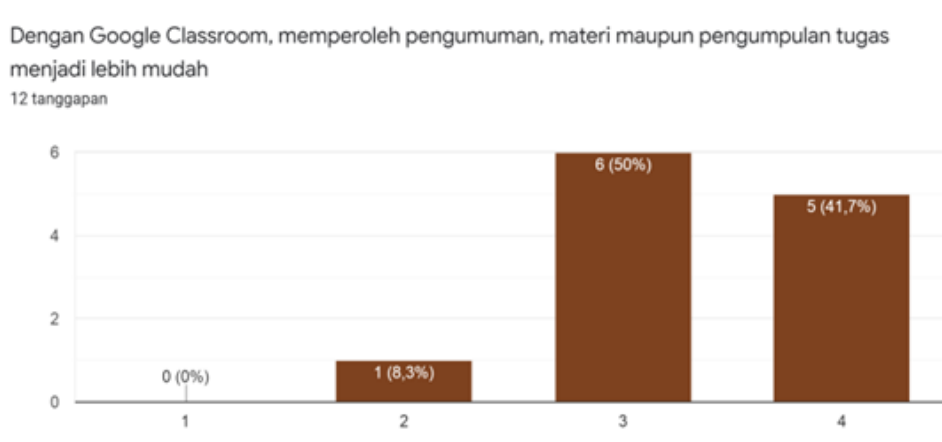

Gambar 10. Histogram pernyataan memperoleh pengumuman materi maupun pengumpulan tugas lebih mudah

Dari Gambar 10, pada positif dan 41,7\% menjawab sangat pernyataan dengan Google positif.

Classroom, memperoleh Dari Gambar 11, diketahui pengumuman, materi maupun bahwa Google Classroom pengumpulan tugas menjadi lebih memudahkan mahasiswa untuk fleksibel menunjukkan $0 \quad \% \quad$ menyimpan dokumen materi maupun menjawab sangat negatif, $8,3 \%$ tugas yang penting berada pada menjawab negatif, 50\% menjawab kategori positif. 
Basri., Idamayanti., Yusdarina. - Analisis Respon Mahasiswa ...

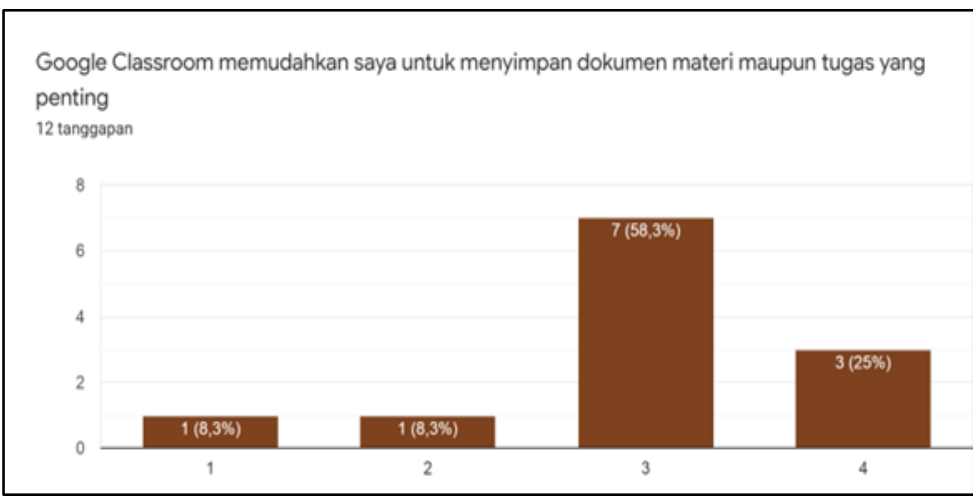

Gambar 11. Histogram pernyataan memudahkan menyimpan dokumen maupun tugas

Selanjutnya, pada pernyataan pernyaataan Google classroom dapat Google classroom dapat menghemat menghemat waktu dan biaya waktu dan biaya, dilihat pada memiliki respon yang sama atau Gambar 12. Berdasarkan data seimbang antara kategori positif dan tersebut dapat disimpulkan pada sangat positif.

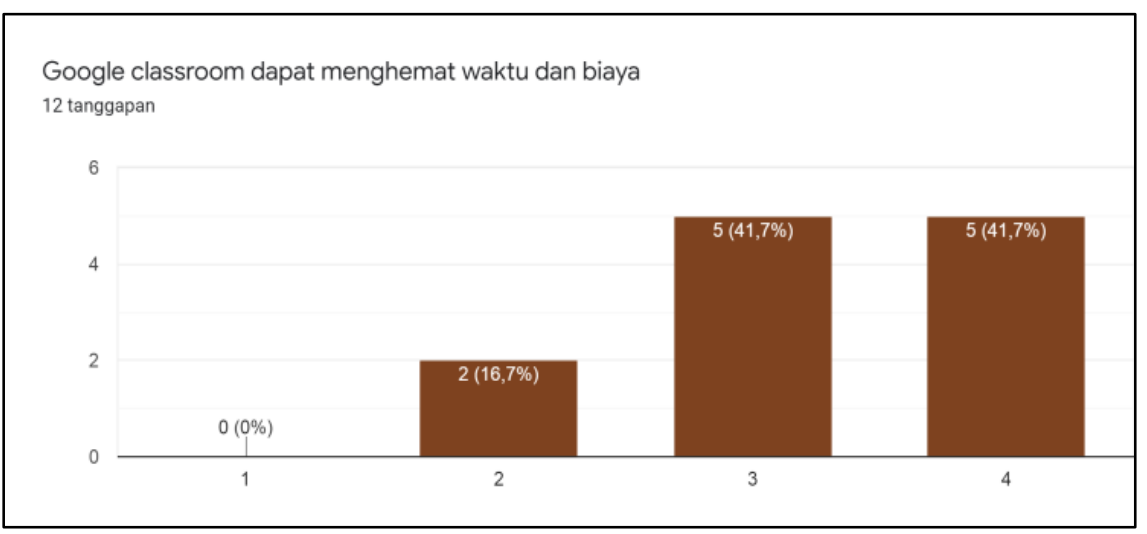

Gambar 12. Histogram pernyataan menghemat waktu dan biaya

Tanggung Jawab Mahasiswa Berdasarkan Gambar 13, respon dalam Pembelajaran Daring

Hasil Penelitian Respon dengan kategori tertinggi berada pada Mahasiswa pada Indikator tanggung jawab mahasiswa pembelajaran respon positif sehingga umumnya mahasiswa memiliki respon positif daring dapat dilihat pada Gambar 13. mengenai tanggung jawab dalam pembelajaran daring. Hasil respon 
Basri., Idamayanti., Yusdarina. - Analisis Respon Mahasiswa ...

mahasiswa pada indikator tanggung jawab dalam pembelajaran daring.

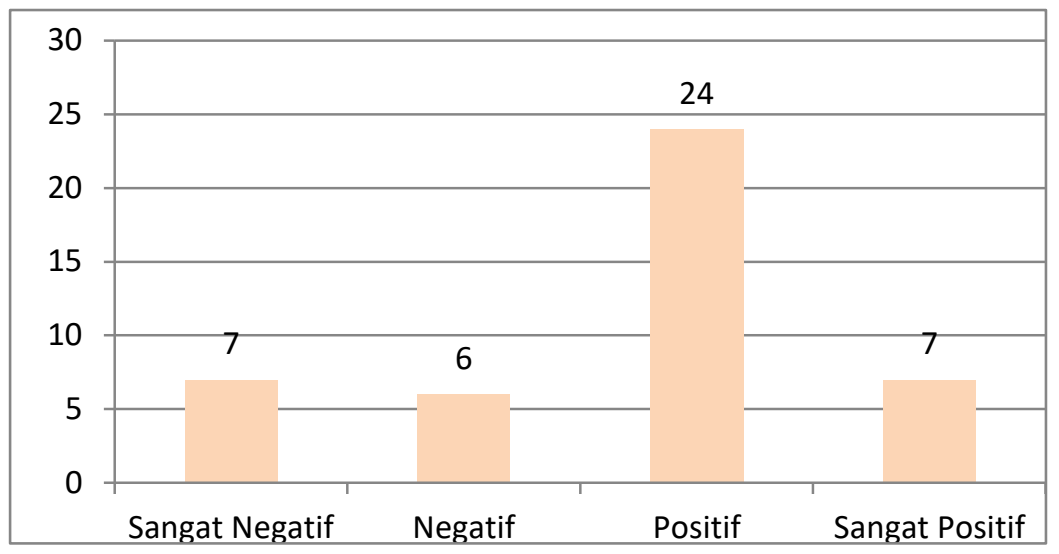

Gambar 13. Grafik Respon Mahasiswa pada Aspek Tanggung Jawab Mahasiswa dalam pembelajaran daring

Respon selanjutnya terkait proses pembelajaran daring, dapat pernyataan mahasiswa lebih dilihat pada Gembar 14. dilihat pada semangat mengerjakan tugas melalui grafik histogram menunjukkan

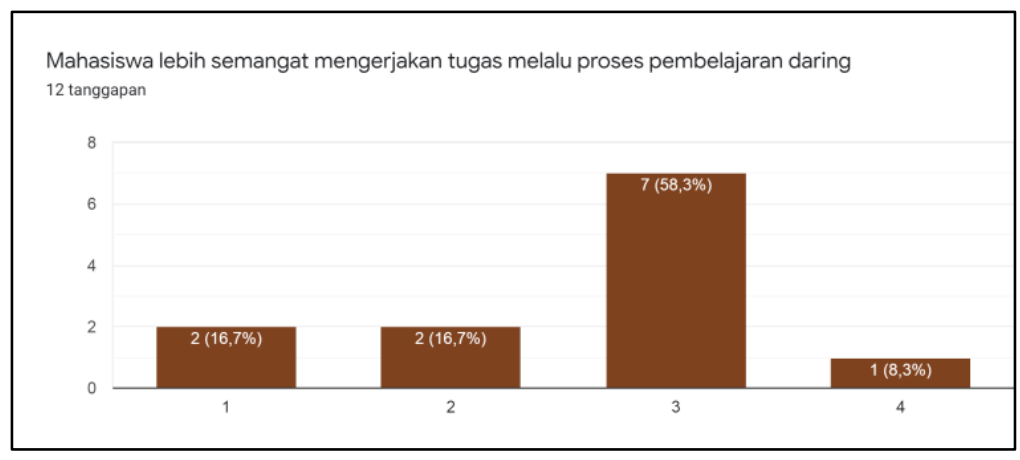

Gambar 14. Histogram pernyataan mahasiswa semangat mengerjakan tugas melalui pembelajaran daring

Gambar 14 menunjukkan bahwa $16,7 \%$ menjawab sangat negatif, $16,7 \%$ menjawab negatif, $58,3 \%$ menjawab positif dan $8,3 \%$ menjawab sangat positif, sehingga dapat disimpulkan pada pernyaataan mahasiswa lebih semangat mengerjakan tugas melalu proses pembelajaran daring berada pada kategori positif.

Selanjutnya, pada pernyataan pembelajaran daring membuat lebih bertanggung jawab dalam mengerjakan tugas, hasilnya dapat dilihat pada Gambar 15. 


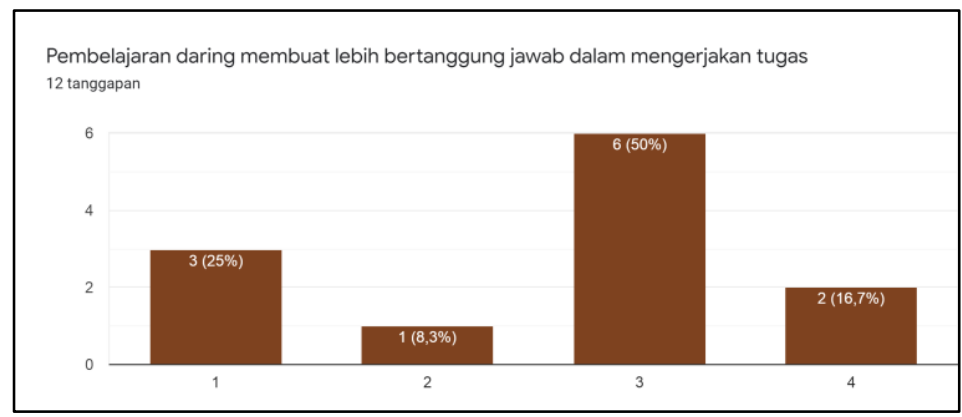

Gambar 15. Histogram Pernyataan Pembelajaran Daring Membuat Lebih Bertanggungjawab Dalam Mengerjakan Tugas

Dari Gambar 15 disimpulkan secara tepat waktu. Hasil respon pada pernyaataan pembelajaran terhadap pertanyaan ini dapat dilihat daring membuat lebih bertanggung pada Gambar 16. Berdasarkan data jawab dalam mengerjakan tugas tersebut dapat disimpulkan pada berada pada kategori positif. pernyaataan pembelajaran daring

Pernyataan selanjutnya terkait megantisipasi pengerjaan tugas secara kemamuan pembelajaran daring tepat waktu berada pada kategori dalam megantisipasi pengerjaan tugas positif.

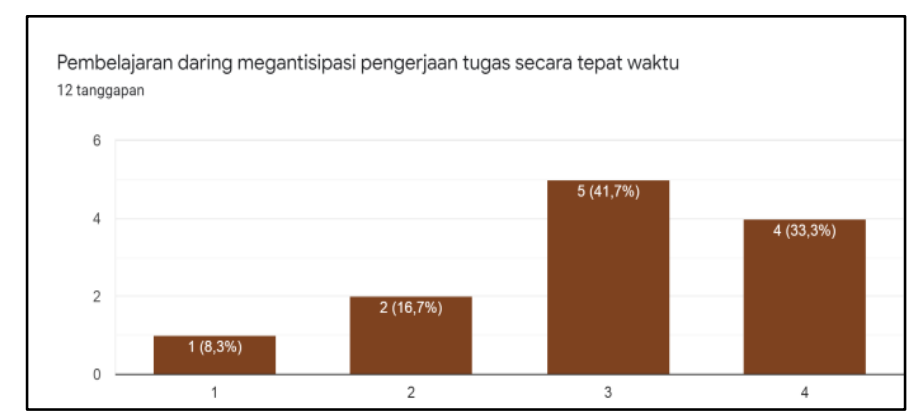

Gambar 16. Histogram pernyataan mengantisipasi pengerjaan tugas secara tepat waktu

\section{Pembahasan}

Untuk melihat respon mahasiswa dalam pembelajaran daring menggunakan google classroom pada mata kuliah pengembangan Bahan Ajar Berbasis Kearifan Lokal dilihat dari efektif dan efisiensi pembelajaran daring dan tanggung jawab mahasiswa dalam pembelajaran daring, dimana dalam mengetahui kedua indikator tersebut mahasiswa diberi beberapa pernyataan yang 
Basri., Idamayanti., Yusdarina. - Analisis Respon Mahasiswa ...

dikirimkan dalam bentuk kuesioner melalui google form yang diisi di pertemuan akhir perkuliahan.

Pada aspek efektif dan efisien dalam pembelajaran daring berdasarkan hasil analisis respon mahasiswa cenderung positif, namun respon mahasiswa sangat positif untuk pernyataan tampilan google classroom jelas dan mudah dipahami, menghemat waktu dan biaya serta kemudahan dalam mengakses google classroom. Hal ini menunjukkan bahwa respon mahasiswa terkait efektif dan efisiensi pembelajaran daring menggunkan media google classroom cenderung positif. Meskipun Rata-rata menjawab positif, namun beberapa mahasiswa menjawab negatif bahkan sangat negatif. Hal ini berarti bahwa mahasiswa memiliki respon positif terhadap pembelajaran daring menggunakan google classroom, namun tidak semua memilki respon positif. Sehinnga pada mata kuliah pengembangan bahan ajar fisika berbasis kearifan lokal mahasiswa cenderung memiliki respon positif dengan pembelajaran daring menggunakan media pembelajaran classroom. Hal ini menunjukkan bahwa pembelajaran daring menggunakan google classroom memiliki dampak positif dimana mahasiswa dapat lebih produktif dalam pembelajaran,menarik perhatian mahasiswa, dan menghewat waktu dan biaya sehingga dapat efektif dan efisien digunakan dalam pembelajaran daring.

Selanjutnya pada indikator tanggung jawab mahasiswa dalam pembeljaran daring hasil penelitian menunjukkan bahwa umumnya mahasiswa menunjukkan respon positif meskipun beberapa mahasiswa juga menunjukkan respon negatif. Sehingga hal ini berarti bahwa tanggung jawab mahasiswa dalam pembelajaran daring pada mata kuliah pengembangan bahan ajar berbasis kearifan lokal cenderung memiliki respon positif.

Berdasarkan hasil penelitian tersebut, menunjukkan bahwa pembelajaran daring menggunakan media google classroom pada mata kuliah pengembangan bahan ajar berbasis kerifan lokal sudah baik dan mahasiswa memiliki respon positif, sebab dalam pembelajaran ini, dosen 
Basri., Idamayanti., Yusdarina. - Analisis Respon Mahasiswa ...

dan mahasiswa berinteraksi dan berdiskusi kapan saja melalui fitur pertanyaan dan pengiriman tugas juga dilakukan melalui fitur tugas, setiap materi perkuliahan dimasukkan sesuai jam perkuliahan yang telah dijadwalkan serta absensi dilakukan melalui fitur classroom juga. Dalam pembelajaran daring ini semua fitur digunakan seperti google meet, google dokumen, menambahkan link, drive, youtube, video, file dan juga membuat slide pun dibuat langsung di classroom serta penilaian juga dilakukan pada google classroom sehingga mahasiswa bisa melihat langsung hasil dari tugas mereka secara langsung tanpa menunggu waktu lama.

Selain itu dosen juga bisa memeriksa plagiarism tugas mahasiswa serta dalam memberikan tugas memberukan batas waktu pengumpulan tugas yang harus dikerjakan oleh mahasiswa. Sehingga dalam pembelajaran daring ini, hampir tidak mengurangi eksistensi tujuan mata kuliah yang diharapkan tercapai. Hasil penelitian ini sejalan dengan Febrilia et al (2020) yang meneliti tentang Analisis Keterlibatan dan Respon Mahasiswa dalam Pembelajaran Daring Menggunakan Google Classroom di Masa Pandemi Covid-19. Hasil riset menunjukkan bahwa Pelaksanaan perkuliahan dengan menggunakan Google Classroom mendapat respon yang positif serta keterlibatan penuh dari mahasiswa karena memberikan atmosfer baru dalam perkuliahan mereka, memudahkan mereka dalam mengakses bahan perkuliahan kapan dan di mana saja. Selain itu, hasil penelitian yang diperoleh sejalan dengan hasil penelitian yang dilakukan (Purba et al., 2020) bahwa pembelajaran google classroom mendapatkan respon yang baik sekali dari mahasiswa.

\section{KESIMPULAN DAN SARAN \\ Kesimpulan}

Berdasarkan hasil penelitian dan pembahasan, dapat diperoleh simpulan bahwa gambaran respon mahasiswa prodi pendidikan fisika terhadap pembelajaran daring menggunakan media pembelajaran google classroom yaitu memiliki respon positif pada mata kuluah pengembangan bahan ajar fisika 
Basri., Idamayanti., Yusdarina. - Analisis Respon Mahasiswa ...

berbasis kearifan lokal di Prodi

Pendidikan Fisika FKIP universitas

Muslim Maros.

\section{Saran}

Diharapkan penelitian ini menjadi sumbangan pemikiran bagi guru dan dosen dalam memilih media pembelajaran selama pembelajaran daring serta peneliti selanjutnya dapat mengembangkan penelitian ini.

\section{DAFTAR PUSTAKA}

Akhmad, N. A. (2019). Analisis Kesulitan Belajar Peserta Didik terhadap Proses Pembelajaran IPA pada Kelas VIII SMP Negeri 1 Barru. Karst: Jurnal Pendidikan Fisika Dan Terapannya, 2(2), 60-63.

Basri, S., \& Handayani, Y. (2021). Pengembangan Mesin Penetas Telur Otomatis sebagai Produk Teknologi Pembelajaran Fisika. Jurnal Ilmiah Wahana Pendidikan, 7(2), 205-215.

Febrilia, B. R. A., Nissa, I. C., Pujilestari, \& Setyawati, D. U. (2020). Analisis Keterlibatan dan Respon Mahasiswa dalam Pembelajaran Daring Menggunakan Google Clasroom di Masa Pandemi Covid-19. FIBONACCI: Jurnal Pendidikan Matematika Dan Matematika, 6(2), 175-184.

Hapsari, S. A., \& Pamungkas, H. (2019). Pemanfaatan Google Classroom Sebagai Media
Pembelajaran Online Di Universitas Dian Nuswantoro. WACANA: Jurnal Ilmiah Ilmu Komunikasi, 18(2), 225-233. https://doi.org/10.32509/wacana. v18i2.924

Nirfayanti, N., \& Nurbaeti, N. (2019). Pengaruh Media Pembelajaran Google Classroom Dalam Pembelajaran Analisis Real Terhadap Motivasi Belajar Mahasiswa. Proximal: Jurnal Penelitian Matematika dan Pendidikan Matematika, 2(1), 50-59.

Purba, F. J. (2020). Analisis respon mahasiswa terhadap penggunaan google classroom sebagai media pembelajaran. Jurnal Curere, 4(2), 11-19.

Sabran, S., \& Sabara, E. (2019, February). Keefektifan Google Classroom sebagai media pembelajaran. In Seminar Nasional LP2M UNM.

Setyosari, P. (2016). Metode Penelitian Pendidikan \& Pengembangan. Prenada Media.

Sugiyono. (2018). Metode Penelitian Pendidikan: Pendekatan Kuantitatif, Kualitatif, dan $R \& D$. Alfabeta.

Utami, R. (2019, February). Analisis Respon Mahasiswa terhadap Penggunaan Google Classroom pada Mata Kuliah Psikologi Pembelajaran Matematika. In Prisma, Prosiding Seminar Nasional Matematika (Vol. 2, pp. 498-502).

Widayati, S. (2020). Respon Mahasiswa Pada Mata Kuliah Daring. Child Education 
Basri., Idamayanti., Yusdarina. - Analisis Respon Mahasiswa ...

Journal, 2(1), 48-52.

https://doi.org/10.33086/cej.v2i1 .1506 